\title{
The Miracle of Music: A Conversation with Ennio Morricone
}

\author{
Emanuele Colombo \\ DePaul University, Chicago \\ ecolombo@depaul.edu
}

\begin{abstract}
In a conversation with Emanuele Colombo, Ennio Morricone-one of the great contemporary composers - discusses the maestro's relation to the Society of Jesus. One of the highlights of this interview is a thin thread that unites the masterful soundtrack Morricone composed for the 1986 movie The Mission (on the Jesuit reducciones in Paraguay) with a Mass he dedicated to the first Jesuit pope, Francis, on the occasion of the 2ooth anniversary of the Society of Jesus's restoration (2014).
\end{abstract}

\section{Keywords}

The Mission (film) - Missa Papae Francisci - indigenous music - sacred music soundtrack - restoration

At the age of eighty-seven, Ennio Morricone is one of the great contemporary composers. With over four hundred movie scores to his name, in 2007 he received the Academy Honorary Award "for his magnificent and multifaceted contributions to the art of film music." Besides six Oscar nominations, in 2016 he received the Academy Award for Best Original Score for his work for Quentin Tarantino's film The Hateful Eight. I met him at his house in Rome to talk about his relationship with the Society of Jesus. Ennio Morricone is bound to the Jesuits by a thin thread that unravels from the soundtrack for the 1986 movie The Mission to the more recent Missa Papae Francisci, premiered in 2015.

The Mission is a 1986 movie about the experience of Jesuit missions in Paraguay. Written by Robert Bolt and directed by Roland Joffé, the movie won the Palme d'Or at Cannes and the Academy Award for Best Cinematography; the film score ranks first on the "Classic 100 Music in the Movies" and was certified

(C) COLOMBO, 2016 DOI 10.1163/22141332-00303007

This is an open access article distributed under the terms of the Creative Commons Attribution- 
"gold" by the Recording Industry Association of America. The Missa Papae Francisci was composed in 2014 to celebrate the bicentenary of the restoration of the Society of Jesus, and was performed for the first time in the Church of the Gesù in Rome on June 10, 2015.

\section{Maestro, you will be back on tour very soon: don't you ever get tired?}

I never get tired of music: it is a passion that does not burn out.

\section{I would like to start our conversation with the soundtrack of The Mission; the music has a key role in the movie...}

First of all, I remember that when the producer Fernando Ghia took me to see the film, as is customary, I immediately liked it. In particular, the final massacre touched me; I told him that I did not want to write any soundtrack, since I thought that the movie was great as it was. "It is beautiful without music," I told Ghia and the British producer, David Puttnam, who was insisting nonetheless. Even Puttnam - who at the beginning wanted to assign the music to Leonard Bernstein, an extremely talented composer, whom, however, they were unable to contact at that time-decided to entrust the soundtrack to me. I was, therefore, their second choice but they did not tell me that at that time; otherwise, because of my pride, I would have probably never accepted. However, not knowing this detail, I accepted it, and it was a fascinating challenge.

The circumstances of the movie put limits on my work in three ways. First, in the movie Father Gabriel played the oboe. What could a man play on an oboe in $175^{\circ}$ if not something typical of the instrumental music of that period? It was crucial that I respected this condition. Second, there was the scene where Cardinal Altamirano walks into a church of the mission and there is a choir. Which kind of choir could that be? It could only be the outcome of the Council of Trent, authoritative and in my view proper, which set the rules of the liturgical music at the time. Before the council, people used to sing religious songs with profane words, and profane songs with religious words. It is a practice that often returns in sacred music and one which recently Benedict XVI rightly tried to correct. The third condition was the traditional music of South America; a music that is repetitive, as primitive music often is. So, I thought of rhythmic pieces.

The soundtrack was born gradually. I wrote the oboe piece first, then the choir piece in a style that would evoke Palestrina, Monteverdi, and other composers, 
and then the indigenous music. In the movie, these three elements are first reproduced individually, and then mixed together. You can hear them all together at the end, after the massacre, when the boy recovers the violin from the water and when you see that Cardinal Altamirano has somehow agreed to move to the Portuguese and the Spanish side. A few years later, the Society of Jesus was suppressed, I do not remember the exact year...

\section{In 1773, by Pope Clement XIV...}

Only twenty-three years later the Society of Jesus was suppressed. Nowadays it is difficult to understand the reasons for its suppression: it was mainly a political decision to please the rulers of Spain and Portugal. In this case, the church gave in to politics, not to the truth.

\section{What kind of work did you do to prepare? Did you study indigenous music?}

I had a general knowledge of indigenous music. It is made of repetitive sounds and rhythms, and short sentences handed down by heart from generation to generation. The idea came to me unwittingly: I decided to insert, as the oboe was entering, the motet-style choir and then add a more rhythmic and local theme. It almost happened unintentionally, a sort of compositional miracle. Everybody really loved the music; it is still a huge success worldwide. But when I think about how the idea was born, I must say that it was either a coincidence or, better, something we might call a little miracle.

\section{The Miserere provides a key to understanding the movie: at the end, after martyrdom, destruction, and death, there is hope, the return of life...}

The image of the cardinal crying is an implicit sign of the church's repentance, which actually bore fruit in history forty years later, when the Society was reestablished in 1814. The final Miserere is a "joyful requiem." You listen to it while the closing credits roll, while in the background you see a young native in the midst of ruins and destruction, collecting the violin instead of a candlestick: it is a gesture that indicates that the education offered by the Jesuits had remained, it had not been completely destroyed. It is a piece of music that I continue to perform today at the conclusion of every concert. 


\section{After more than four hundred film scores, you wrote a Mass...}

Yes, the story about the Mass dates back to three years ago. Every day at seven in the morning, I go to buy the newspapers in Piazza del Gesù, at the newsstand in front of the Gesù Church. One day in 2013, I met Father Daniele Libanori, the rector of the Church of the Gesù, who asked me to write a Mass. My wife has been asking me to write a Mass for several years but I have always refused, even though I had already written religious music_-including a cantata with words by John Paul II and a very mystical piece of music with beautiful lyrics by the Italian contemporary composer Francesco De Melis, Vuoto d'anima piena, written for the millennium of the Cathedral of Sarsina, in northern Italy. I was not persuaded to write the Mass, but I kept an open mind with Fr. Libanori and told him: "Look, I am not sure I will write it. Give me the lyrics and I will call you when I am done, if I am able to finish. Otherwise I will call you to let you know that I was not able to do it." In fact, I called him to let him know that I had finished it! The reason why I had never accepted my wife's requests was bound to the circumstances of its execution: Fr. Libanori's proposal was not only to write a Mass, but also to perform it for the two-hundredth anniversary of the restoration of the Society. I composed it thinking about the occasion, the audience, the Society of Jesus. Perhaps I had never written a Mass before, despite the requests of my wife, because I needed an occasion for doing so. The idea of performing the Mass for that important anniversary persuaded me.

\section{The Mass has two dedications...}

Yes, to my wife Maria and to the pope, the first Jesuit pope. More than a year ago, I handed the pope the score and I told him the story behind it as I am telling you now. We spent ten minutes together. I was so happy, and I could not speak because of the emotion; he gave me two rosaries, since my wife was with me. I told him the story of the Mass and I added: "Holy Father, I count on Your presence, this is not an ordinary concert, it has a great importance for me."

\section{Which part of the Mass do you like the most?}

I like the introduction. I used it also in a Way of the Cross I wrote together with other composers. It is a passage that I really care about, because it is a musical invention. The written score is in the shape of a cross - we could say that it is a 
"musical cross": at the beginning, there are two horns that follow two different long melodies, then the trumpet that makes a soft and light sound, and then comes the vertical dimension of the orchestra. Eventually, the cross takes form and twelve different sounds are created, in multiples of three. I wrote it thinking about the Trinity. In this piece, the choir-which could be done with the participation of the audience as well-says a quiet prayer while the orchestra is playing. It is as if it was the crowd saying these words. It lasts one and a half minutes, after which the Mass begins with the Kyrie.

\section{Why didn't you use the violins?}

I removed violins and violas because they gave a sappy touch to it that I did not like. Flutes, oboes, clarinets, and bassoons are missing too. It was not a full orchestra, but you can find the percussion, five trumpets, horns, trombones, and two organs. Finally, there are two choirs, because I wanted to be faithful to the Venetian tradition of Adrian Willaert (c.1490-1562) and of Andrea (c.1533-85) and Giovanni Gabrieli (c.1554-1612), the founders of the Venetian polychoral school that made an extensive use of two split choirs (cori spezzati), creating the effect of a dialogue between two performing groups. In the Basilica of San Marco, in fact, there are two choirs, one to the right and one to left. I, therefore, remained loyal to this tradition. However, you can also notice some breaks from tradition: not because I wanted to be revolutionary no matter what, but because I like to be challenged, to always find new forms. Therefore, I used polymodality (the combining of different musical modes), even inserting some dissonances. I took some liberties but the piece is clearly liturgical, with some experiments in the background of the track.

\section{For example, in the Gloria...}

Exactly. In the Gloria there are several dissonances that you do not grasp immediately because they are scattered, distant. However, they are present and that is something new for a Mass. I started from tradition, but then I introduced dissonant sounds. In the Agnus Dei, I tried to use the echo as an expressive element, which plays and runs from the right to the left of the choir, with a final quote from the music of The Mission. The end was not great during the execution in the Church of the Gesù because the echo 
mixed the sounds. The performance was good, but the echo partially compromised it.

The end of the Mass is full of hope; in a Mass written for the anniversary of the restoration of the Society, it seems to say: "It begins again!" And the quotation from The Mission seems to say that the restored Society can begin its life again...

Yes, and also here I would use the term "joyful requiem," like the end of The Mission. There is suffering, but there is also hope.

\section{What can we find in this Mass that belongs to the soundtrack- composer Ennio Morricone?}

I cannot deny my style. I will always be myself. Of course, when I compose soundtracks for movies, the plot, the images, and discussions with the director influence me. In the case of this Mass, I was not influenced by anyone, and my personality always emerges. You can recognize my style in both my music for the cinema and in other compositions. Again, this Mass is loyal to the liturgical traditions, as you can hear from the Gregorian traits that are present, even though, as I mentioned before, there are breaks with the tradition with the use of polymodality.

\section{Have you always had an attraction for sacred music?}

Let me tell you a story. The first soundtrack I wrote was for a movie directed by Luciano Salce in 1961, The Fascist [Il Federale], and then I worked with him on five, six, or maybe seven other movies, I do not remember. He always called me. Actually, he had called me even before The Fascist, to compose the soundtrack for Hercules' Pills [Le pillole di Ercole] (1960), but the producer of the movie, Dino De Laurentiis, chose another composer since I was a stranger to him. However, the two co-producers of The Fascist, Renato Libassi and Isidoro Broggi, chose me for the score. Since then, I began to write music also for other directors. One day, Salce called me and told me in a friendly way: "I discovered that you are a mystical composer. I make comedies, I do not think you should work with me in the future." Besides the fact that he was wrong, since I have often written good music for comedies, he thought that I had this sense of mysticism and a sensibility for the sacred. 


\section{Do you agree? Is it so?}

He told me so! I did not know, I swear! I was not looking for this trait. It came out from me and it still endures. Salce and I have been friends ever since, even though he was wrong because my music for comic movies was beautiful anyway. After me, he always chose the wrong composer! However, it is true that my personality unintentionally developed to incorporate this sense of sacredness over time in composing for tragedies and dramas.

\section{What do you think of sacred music today?}

I don't think there is much today. There is Marco Frisina, a priest, who is a dear friend of mine, who was first in San Giovanni and now he is at the Basilica of Santa Cecilia. His compositions are really good, but there isn't an official sacred music today. There was the great composer Domenico Bartolucci, who, however, wrote music in the most pure tradition. He probably wouldn't even like the Mass I wrote. He used to compose only choral songs, four voices that sing according to the post-Tridentine norms.

\section{And how about the songs used in church during the liturgy?}

I heard that people often sing as before the Council of Trent: sacred texts accompanied by profane music, and vice versa. I don't like such confusion; Benedict XVI has tried to correct this attitude but he succeeded only partially. However, Gregorian chant will always exist: this absolute monody is a great resource.

\section{I want to go back to the series of connections between you and the Jesuits: the movie first, then the Mass, and then your personal history. How do you see the Jesuits today? Moreover, you celebrated the restoration of the Society: what do you think about it? How do you see them in the history of the church and in the history of the world?}

Somehow, I participated in the suppression of the Society with the music of The Mission, and now I take part in the anniversary of its restoration. And then I met the pope, the first Jesuit pope. In all these coincidences, I find something almost miraculous. As regards the Jesuits, I believe that they are the religious order with more "thinkers." I read their excellent journal the Civiltà cattolica; it seems to me that the Jesuits are, with all due respect for everyone else, the 
highest order in the church. And they don't praise themselves for that. Here in Rome they run a school, the Collegio Massimo, where my children went to study: the teachers are talented and strict in the right way.

\section{Are you planning to offer concerts in the United States?}

Not at present. If I want to go to the United States, I have to schedule at least five or six concerts. Then, there would be many other problems because I want to control the orchestra. Here, I can control everything. And then there is the choir... When I recorded the music for the movie The Exorcist II in the United States, at first I was very worried about the voices.

\section{You didn't like them?}

Well, I did not know what to expect and I was afraid not to find what I needed. The delicacy of the voice is a decisive factor; the voice is the most important sound that comes from within us, and therefore it is a delicate thing. For the recording of The Exorcist II I was very worried, and so I arrived in Los Angeles several days before the recording to listen to the choir. One morning I went there while they were rehearsing. I walked by the studio, and I was so surprised-I still feel like crying now: the voices were extraordinary! In the movie there is also what I call the "African-Flemish Mass."

\section{African-Flemish?}

The singers were all African-Americans, and I wrote that Mass together as a single piece (The Kyrie, the Gloria, and the Agnus Dei), and all voices were singing together [the combination of different texts in the same composition was a favorite technique of Renaissance Flemish composers]. The movie's director John Boorman, who is Irish, was enthusiastic.

Last question: people all over the world love your movie soundtracks, which are the more accessible pieces, and only a few people listen and understand your more elaborate pieces; do you regret this?

No, I understand this very well and I see it at concerts. The audience is very diverse: there are very young people and the elderly. I cannot complain if they 
applaud less the cantata Voci dal silenzio, a composition that I wrote for the September 11 attacks and that I dedicated to all the massacres of mankind-a piece that maestro Riccardo Muti conducted both in Ravenna and in Chicago. I am used to the excitement of the audience for my most famous pieces. The audience jumps up, sometimes at the end of the concert or sometimes at the end of each song! I have to say that I am happy and proud of that. This is the reason why I keep going and continue to conduct concerts at the age of eighty-seven.

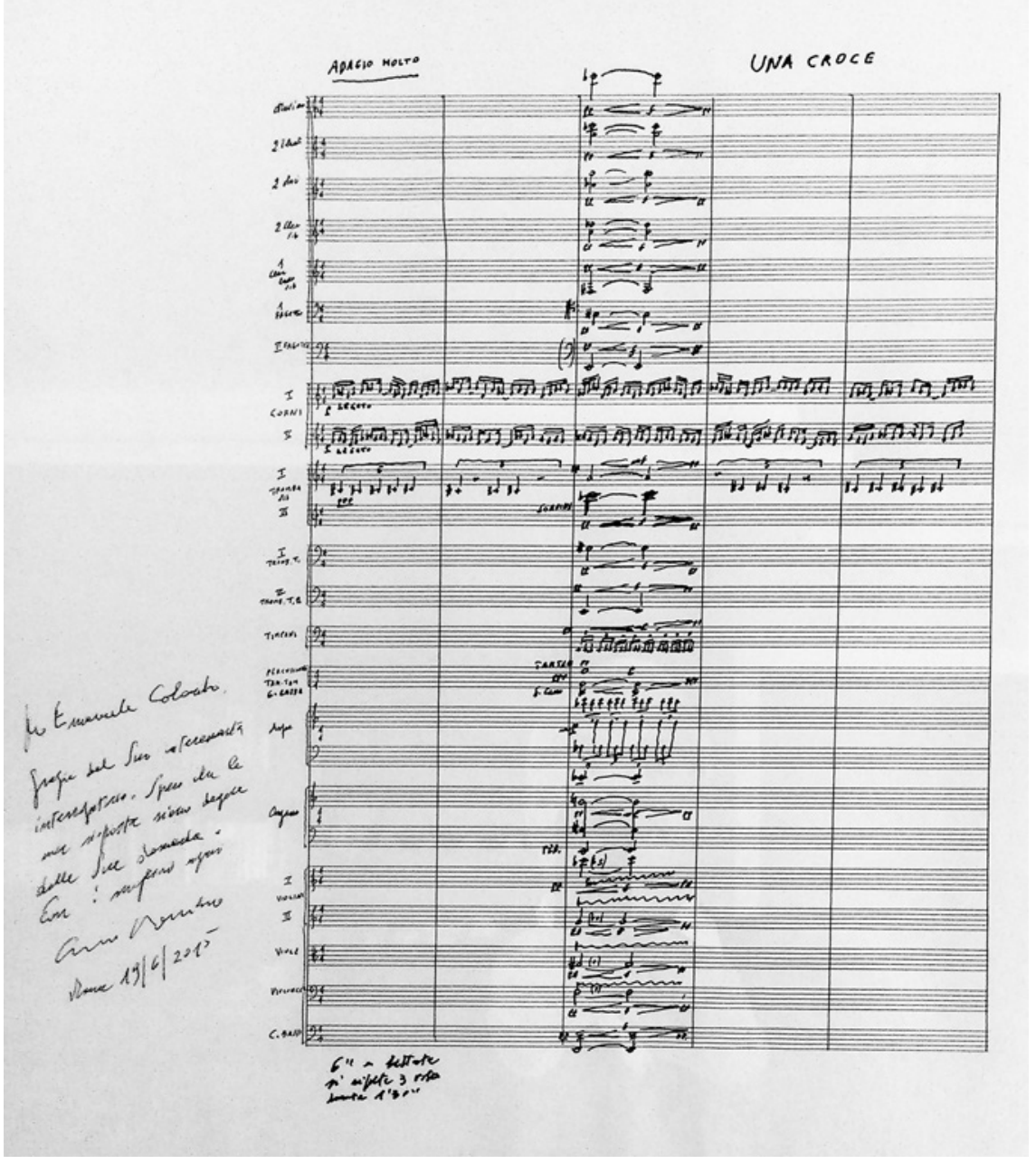

A fragment of Ennio Morricone, Una via crucis [ "Way of the Cross" in various vocal and instrumental combinations and in collaboration with Michele Dall'Ongaro and Egisto Macchi], 1991-93, with a dedication to Emanuele Colombo. COURTESY OF THE COMPOSER. ALL RIGHTS RESERVED. 